\title{
ECONOMIC ASPECTS OF FARMING DEVELOPMENT
}

\author{
H. J. Plunkett
}

\section{Farm Advisory Officer (Economics), Dunedin}

\begin{abstract}
"The country needs overseas funds." This is .a plea that is often heard and is akin to the statements that all dry. land needs irrigation, and all farmers Rolls Royces. A logical approach to the subject of overseas funds is to determine what could be done if overseas funds were available and what has got to be sacrificed to obtain them. A rational person, when making a decision, measures his need for an object and weighs his need against what has to be given to obtain that object. There are no Rolls Royces outside. It can only be assumed that the people assembled do not consider the extra technical performance and prestige value of a Rolls Royce worth the monetary sacrifice. The plea that N ew Zealand needs overseas funds must also be critically assessed. The fact that overseas countries have a bigger variety of better quality and cheaper goods

' demonstrates the need for overseas trade. New Zealand needs overseas funds in order to trade with these countries. The important questions the country faces are: (1) What has to be sacrificed to obtain the overseas funds? and (2) If something must be given up to obtain the overseas funds, is the sacrifice worth while?

Some people believed-perhaps some still do-that if a product could not be manufactured in N ew Zealand the country could do without it. This type of plea was advanced in the fifties by people advocating diversification of production. The relevant question is not one of whether or not a product can be manufactured in New Zealand. If enough resources are spent on manufacturing, anything produced overseas could be produced in $\mathrm{New}$ Zealand. The country could have a space research programme if it could get the economy to earn enough and then was prepared to spend everything on space research. The disadvantage of diversification is that it can lead to gross inefficiency. For example, the spending of E1 overseas funds
\end{abstract}


on raw materials and $£ 2 \mathrm{~N} . \mathrm{Z}$. in manufacturing costs, to save $£ 2$ overseas funds on a finished article represents a waste of resources. It is much more efficient to spend $£ 2$ N.Z. in an export industry and obtain $£ 2$ overseas funds in return.

Work in the late 1950s and early 1960s revealed the startling facts that if $\mathrm{New}$ Zealand was going to support a $2 \%$ rise in population as well as increase the standard of living by $2 \%$ per year exports would have to rise quite sharply or there would be unemployment or a decline in the standard of living. Agriculture was the only sector of the country's economy that offered any hope of achieving the necessary overseas funds. The targets committee of the Agricultural Development Conference (1964) estimated that 111 million ewe equivalents would be required by 1972. Investigational work by Professor B. P. Philpott (1963) suggested that to achieve this increased production there would have to be $\mathrm{f} 400$ to $E 600$ million invested in agriculture in the next 8 to 10 years. This represents about E45 million annually. The required investment is about double that which occurred during the fifties. These facts indicated that farmers and financial institutions required a new approach to agricultural credit. The question then arose as to whether this investment would be worth while. Based on the results of the fifties, the work by Professor Philpott indicated that this investment was likely to yield $15 \%$ to $20 \%$.

\section{The Farmer}

Farm development is a method whereby a farmer may 'achieve his goal in life. Usually this consists of enabling the farmer to have a more valuable asset and a greater take-home pay. This may not be true in all cases. For any individual farmer, development is economically justified only if the benefits of a more valuable asset and a greater take-home pay are greater than the cost of obtaining them.

The statement that the country needs overseas funds and the justification of that statement are not likely to achieve any results unless farm development is made attractive to the individual farmer. If development is not attractive to farmers, it is certain that it will not be done. Everybody has a certain amount of patriotism but a person's patriotism does not extend very far when, because 
of it, he is in a worse position than his unpatriotic neighbour.

The profitability of a farm to a farmer is governed by the market value of the property and the net farm profit the property is producing. For example, consider two farms, $A$ and $B$, of 1,000 acres each, where both farms are producing a net farm profit of $£ 4,000$. Farm $A$ has a market value of $£ 30,000$ while farm $B$ has a market value of $£ 60,000$. Under these conditions, farm $A$ would be the more profitable because it earns a greater return on capital. A nother farm, C, which was of the same value as farm A, earning the same net farm profit and $£ 10,000$ more valuable in 5 years' time, would be the more profitable farm to own. This example indicates that there are two aspects of profitability which must be considered: (1) Capital gain; (2) Net farm profit.

The value of a farm can also be expressed in two ways. This farm is worth $\mathfrak{E x}$ or this farm gives a net farm profit of $\mathfrak{E x}$ per year. In theory, the two should be perfectly equated by the market rate of interest. For example a person is given the choice between $£ 5$ per annum and a f 100 lump sum. The market rate of interest is $5 \%$. Under these conditions, a rational person would be indifferent as to which alternative to select. The reason is that both alternatives give the same result. The 100 may be invested at $5 \%$ and provide an annual income of $£ 5$. In actual practice, capital value and net farm profit are not perfectly related. The reasons for the discrepancies are such factors as the attractiveness of a property, the price and technological uncertainties of the future, individuals' varying time preferences for money, and legislation.

The profitability of a development programme is usually found by comparing the returns of the farm before and after development. All the costs and returns of the development are taken account of and brought to a common basis. If the returns exceed the costs then the development is profitable. In practice, for an individual the change in the take-home pay brought about by a de velopment programme is not usually perfectly equated with the change in market value of the property. This is one of the problems confronting the people concerned with evaluating profitability of development. If, because of the general attractiveness of the property as a result 
of development, the increase in- market value is greater than the increase in take-home pay, then the overall profitability of the development is increased. The converse applies when people go on to the market to buy land for development and pay well in excess of the productive value of the undeveloped land. The overall profitability of the venture may be far less than is indicated by considering only change in annual take-home pay. Research workers, when considering the profitability of development programmes, usually confine themselves to considering changes in take-home pay as they are concerned with what development will do to a farm's productive ability. They are not directly concerned with what people consider development has done or will do to the market value. Market value changes are important when an individual is contemplating buying, selling or raising additional finance.

\section{Factors which Affect Profitability}

\section{The Human Element}

The success of any development programme ultimately rests with the person who has to carry it out. A farmer contemplating development is also concerned with factors other than the financial outcome of the development programme. He must also consider the increases in risk, worry and work associated with farm development. Detailed forward planning is the only method that provides an accurate forecast of what the changes in these factors are likely to be. For a development programme to be completely acceptable to the individual who must carry it out, it must be sufficiently profitable to compensate him for the changes that will occur in risk, worry and work.

Other papers in these Proceedings deal with potentials and ways in which they may be achieved. In the calculation of them it is assumed that every farm is the right size, has the right amount of capital and is run by the "potential man". Fortunately or unfortunately, depending upon how it is viewed, all farms are not the right size, have not the optimum amount of capital and do not have the potential man as a manager. These factors considerably lower the level of production of farms. The following figures revealed by the committee of inquiry into the Proposed Maniototo Irrigation Scheme illustrate 
this point. The present carrying capacity of the plain was considered to be 73,000 ewe equivalents, while the readily obtainable dryland potential was 100,000 ewe equivalents. Lack of optimum farm size, capital and "potential men" has meant that this area has a 73\% level of achievement under dryland farming.

Farm ownership is dependent upon having or getting the right parents or through working the way up from the bottom. Increases in farm mechanization and capitalization on farms has meant the second method is more difficult than it was a generation ago. It appears likely to become even more difficult in the future. These two methods of obtaining farms determine who are to be the farmers in the future. They may or may not be the best methods for selecting the "potential men" who will be necessary if a district is ever to reach its potential.

\section{Sтоск}

With the exception of cropping farms, the profit on farms comes from livestock. Profit can arise from the increases in productivity of the existing livestock or through increases in their numbers or by a combination of the two.

Money which has been spent on development can be recovered in two ways:

(1) Capital gains from sale of the farm.

(2) The increased sale of livestock or livestock products.

The profitability of development is governed by the increases in livestock and their relationship to development costs. Development should therefore be planned on per stock increase expected and not on a per acre basis. The greater the stock increases per El spent the greater will be the profitability. Stock increases and where they are going to come from are frequently given only minor consideration in development plans. A method of development which results in low profits, or even losses, is to complete the physical development before considering how the stock are to be increased. Stock increases and money to obtain the increases should be planned along with the physical development. Planning development of a property for increases in profit from an increase in stock unit production is likely to be profitable only when the property is already overstocked. 
LABOUR

Men come in units of one although some are thought to have a usefulness of a fraction greater or smaller than this. Increasing stock numbers with development raises the problem of when the next unit should be employed. In development it pays to increase the breeding flock to the limits of the existing labour. The additional stock should be carried by making use of labour-saving methods such as employing contractors to do some of the farm work (e.g., fencing), running a dry flock or cattle. With the use of these and similar methods, sufficient stock may be carried to utilize the extra grass grown. An additional labour unit should be employed when development has increased the carrying capacity of the farm sufficiently to profitably employ the additional labour. To facilitate the profitable employment of labour a change may be made from dry stock or cattle to the more profitable and higher labour demanding breeding ewe flock.

T A X A T I O N

Taxation always reduces the take-home pay of any occupation and farming is no exception. Under the existing legislation; the complete deductibility of some forms of development expenditure (fencing, fertilizer etc.) allows capital gains to be made without tax being incurred. This is an incentive to development which is available to farmers and no other sector of the economy. There are other pieces of legislation that can be positive incentives for development in certain circumstances, but what help they are depends upon individual circumstances.

Other research workers have found that, for people with high rates of taxation, development tends to be more profitable after tax than before; however, high rates of taxation have a negative effect in encouraging such people to want more profit.

\section{Method of Development}

In most districts, methods of development are well known. There are usually only one or two methods which are considered suitable for developing a given class of country. It is not the method but the manner in which a given development programme is implemented that is 
the main determinant of profitability. If the land is ploughable, it does not necessarily mean that the most profitable method of development is by cultivation. Cultivation is likely to be more profitable only when it can combat a weed problem more cheaply (e.g., gorse) or where it allows a more rapid build-up in stock numbers.

If finance is limited on a property, and the land could be developed with equal profitability by either oversowing and topdressing or cultivation, then the method which requires the least overdraft per ewe increase is the most profitable. In other words, the method resulting in the greatest stock increase for a given input of capital will give the maximum net farm profit.

Table 1 is an elementary model to illustrate this point. It indicates that for a $£ 100$ overdraft there could be an increase of 21 sheep with cultivation or an increase of 100 sheep with oversowing and topdressing.

TABLE 1: COMPARISON OF THE OVERDRAFT REQUIREMENTS FOR OVERSOWING AND TOPDRESSING AND CULTIVATION

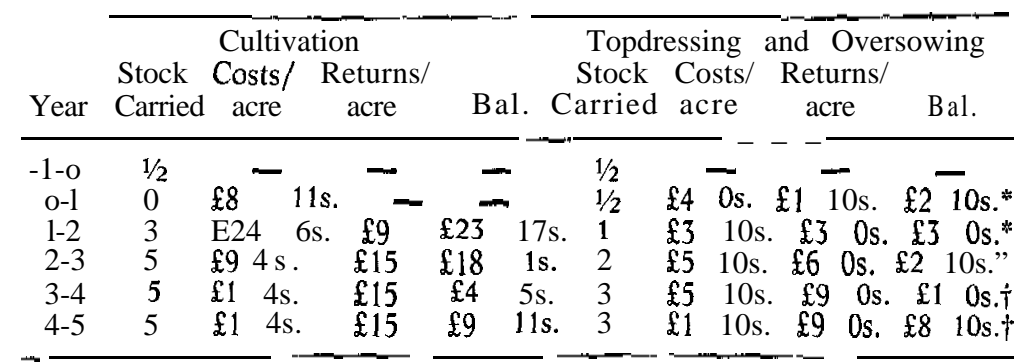

"Minus balance

†Plus balance

Another problem associated with development is whether the extra stock needed for development should be bought or bred on the property. There is no simple answer which can be given when considering the economics of replacement policies. One of the contentious issues in such an analysis is the conversion ratio of ewe hoggets for ewes. The critical factor is not necessarily the ratio of the feed requirement of the two for the whole year-it is more likely to be the ratio of feed requirements in the period of the year when feed is limiting. Whether this is the appropriate ratio will depend upon the availability of 
feed at different times of the year and the management system. Should the limiting period be the winter, the appropriate ratio of ewe hoggets to ewes may be 0.75 to 1.0 ; if it is the summer it may be 1.0 to 1.0 , and if it is the spring-summer it may be 0.5 to 1.0. The most profitable stock policy for a particular farm will vary as market conditions change. Table 2 shows 'a financial comparison of three different methods of maintaining a ewe flock. These methods are (1) Buying in 2-tooths; (2) Buying in 2-year ewes; (3) Breeding own replacements.

TABLE 2: FINANCIAL COMPARISON OF THREE DIFFERENT METHODS OF MAINTAINING A EWE FLOCK

\begin{tabular}{|c|c|c|c|c|c|c|c|}
\hline & & \multicolumn{3}{|c|}{ Buying in 2-tooths } & \multicolumn{3}{|c|}{ Buving in 2-yr Ewes } \\
\hline & & S.U. & No. & B.E. & S.U. & No. & B.E. \\
\hline E.H. & $\ldots$ & - & - & & - & - & \\
\hline 2-th & & 220 & 220 & & - & $=$ & \\
\hline 4-th & $\ldots$ & 210 & 210 & & _ & 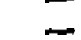 & \\
\hline 6-th & $\ldots$ & 200 & 200 & & & - & \\
\hline \multirow{3}{*}{$\begin{array}{l}\text { F.M. } \\
\text { 5yr }\end{array}$} & $\ldots$ & 190 & 190 & & 512 & 512 & \\
\hline & $\ldots$ & 180 & 180 & 1,000 & 488 & 488 & 1,000 \\
\hline & & 1,000 & 1,000 & & 1,000 & 1,000 & \\
\hline Sale & $\ldots$ & C.F.A. & 170 & & & 476 & \\
\hline
\end{tabular}

Breeding own Replacements

\begin{tabular}{|c|c|c|c|c|c|c|c|c|c|c|c|}
\hline & & \multicolumn{2}{|c|}{$\begin{array}{l}\text { (a) At } 0.5 \\
\text { S.U./E.H. }\end{array}$} & \multirow[b]{2}{*}{ B.E. } & \multicolumn{2}{|c|}{$\begin{array}{l}\text { (b) At } 0.7 \overline{5} \\
\text { S.U./E.H. }\end{array}$} & & \multicolumn{3}{|c|}{$\begin{array}{l}\text { (c) At } 1.0 \\
\text { S.U./E.H. }\end{array}$} \\
\hline & & S.U. & No. & & S.U. & No. & B.E. & S.U. & No. & B.E. & \\
\hline E.H. & & 103 & 206 & & 147 & 196 & & 187 & 187 & & \\
\hline 2-th & & 197 & 197 & & 187 & 187 & & 179 & 179 & & ' \\
\hline & $\ldots$ & 188 & 188 & & 179 & 179 & & 171 & 171 & & \\
\hline 6-th & $\ldots$ & 179 & 179 & & 171 & 171 & & 163 & 163 & & \\
\hline F.M. & $\ldots$ & 171 & 171 & & 162 & 162 & & 154 & 154 & & \\
\hline \multirow[t]{2}{*}{$5 \mathrm{yr}$} & $\ldots$ & 161 & 161 & 896 & 154 & 154 & 853 & 146 & 146 & 813 & \\
\hline & & 999 & 1,102 & & 1,000 & 1,049 & & 1,000 & 1,000 & & \\
\hline Sale. & $\ldots$ & C.F.A & A. 152 & & & 145 & & & 138 & & \\
\hline
\end{tabular}


The following assumptions have been used in the comparison :

(1) A $110 \%$ survival to sale lambing percentage.

(2) An increase of $10 \%$ in lambing percentage with 2year ewes.

(3) All sheep clip $10 \mathrm{lb}$ of wool. The bought-in 2-year ewes clip $1 \mathrm{lb}$ less.

(4) A death rate of $5 \%$.

Comparison with Buying in Two-tooths

$$
\begin{aligned}
& \text { Buying in } \\
& \text { 2-yr Ewes }
\end{aligned}
$$

A. Reductions in Revenue

(1) Less Wool Pro- $1,000 \mathrm{lb}$

duced @ 3s.4d.....

(2) Less Iambs sold -bred -replacements

(3) Less C.F.A. sales

(a) 30s.....

(4) Purchases of 2-yr ewes

Total A

$£ 167$

512
Breeding Replacements
(a)
(b)
(c)

\begin{tabular}{|c|c|c|}
\hline$£ 1,536$ & - & - \\
\hline$£ 1,703$ & $£ 747$ & $£ 844$ \\
\hline
\end{tabular}

$\begin{array}{cccccc}114 & & 162 & & 206 & \\ 206 & & 196 & & 187 & \\ & £ 720 & & £ 806 & & £ 884 \\ 18 & & 25 & & 32 & \\ & £ 27 & & £ 38 & & £ 48\end{array}$

B. Increases in Revenue

(1) More lamb sales

(a) 2.25

(2) More C.F.A. sales

(a) $30 \mathrm{~s} . . .$.

(3) More wool (lb)

(a) 3s. 4d.....

(4) Saving in 2-th replacement

(a) £5 ...:

(5) Saving in ram re-

placements

100

$306 \quad £ 225$

$£ 459$

Total B

$$
\begin{aligned}
& 1,020 \quad \stackrel{1}{170} 490 \quad £ 82
\end{aligned}
$$

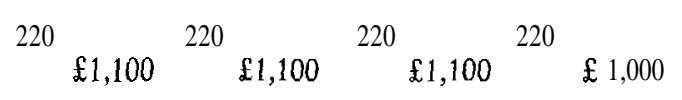

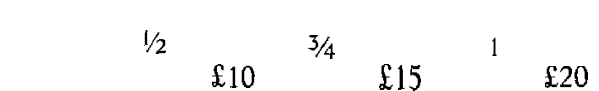

\begin{tabular}{|c|c|c|c|}
\hline $\mathfrak{£} 1,784$ & $\begin{array}{l}- \\
£ 1,280\end{array}$ & $£ 1,197$ & $\bar{£} \overline{£ 1,120}$ \\
\hline $\mathfrak{L} 81$ & $£ 533$ & $£ 353$ & $£ 188$ \\
\hline
\end{tabular}

Benefit above buying 2-th ( ( B - A ) 
(5) A ram ratio of 1 ram to 50 ewes.

(6) Market Prices :

Sale lambs.... $\quad \ldots \quad \ldots 4$ 45s, on the place

Purchase price for 2-tooths .... 100s. on the place Purchase price for 2-year ewes 60s. on the place Purchase price for rams .... $£ 20$ on the place Wool price.... .... ... . 3s. 4d. per lb net.

Age Composition of Flock:

Age-balanced flocks requiring 1,000 stock units (S.U.s) of feed.

From the analysis it can be seen that the most critical factors governing what is likely to be the most profitable alternative are the market prices of the replacement stock and the price of wool relative to the price of lamb.

\section{Conclusion}

Farm development is in the national interest and should continue to be encouraged. For the individual farmer, development is a challenge which, if well planned and executed, can be highly rewarding.

\section{Acknowledgement}

D. K. Crump, Farm Advisory Officer (Economics), Dunedin, for assistance given in the preparation of this paper.

\section{REFERENCES}

Agricultural Development Conference, 1964: Report of the targets committee.

Philpott, B. P., 1963: Proc. N.Z. Inst. agric. Sci., 9: 175-87. 